\title{
Red, Green, and Blue Electrochromism in Ambipolar Polylamine-amide- imide)s Based on Electroactive Tetraphenyl-p-Phenylenediamine Units
}

\author{
LI-TING HUANG, HUNG-JU YEN, CHA-WEN CHANG,* GUEY-SHENG LIOU \\ Functional Polymeric Materials Laboratory, Institute of Polymer Science and Engineering, National Taiwan University, \\ 1 Roosevelt Road, 4th Section, Taipei 10617, Taiwan
}

Received 25 June 2010; accepted 29 July 2010

DOI: $10.1002 /$ pola.24266

Published online 20 September 2010 in Wiley Online Library (wileyonlinelibrary.com).

\begin{abstract}
A series of novel poly(amine-amide-imide)s (PAAls) based on tetraphenyl-p-phenylenediamine (TPPA) units showing anodically/cathodically electrochromic characteristic with three primary colors [red, green, and blue (RGB)] were prepared from the direct polycondensation of the TPPA-based diamine monomer with various aromatic bis(trimellitimide)s. These multicolored electrochromic polymers were readily soluble in polar organic solvents and showed excellent thermal stability associated with high glass-transition temperatures $\left(288-314{ }^{\circ} \mathrm{C}\right)$ and high-char yield (higher than $60 \%$ at $800{ }^{\circ} \mathrm{C}$ in nitrogen). The PAAI films revealed electrochemical oxidation and reduction accompa-
\end{abstract}

nied with high contrast of optical transmittance color changes from the pale yellow neutral state to the green/blue oxidized state and red reduced state, respectively. The electrochromic films had high-coloration efficiency (CE $=178$ and $242 \mathrm{~cm}^{2} / \mathrm{C}$ at the first and the second stages, respectively), low-switching time, and good redox stability, which still retained a high electroactivity after long-term redox cycles. (C) 2010 Wiley Periodicals, Inc. J Polym Sci Part A: Polym Chem 48: 4747-4757, 2010

KEYWORDS: electrochemistry; electrochromism; functionalization of polymers; polyimides; triphenylamine
INTRODUCTION Electrochromic materials show a reversible optical change ability in absorption or transmittance upon electrochemically oxidized or reduced, which has stimulated the interest of scientists over the past decades. ${ }^{1}$ Early, investigation of electrochromic materials has been interested in optical properties in the visible region change (400-800 nm), proved useful and variable applications such as e-paper, optical switching devices, smart window, and camouflage materials. ${ }^{2}$ There are many intrinsically electrochromic materials, such as transition-metal oxides, inorganic coordination complexes, organic molecules, and conjugated polymers. ${ }^{3}$ Increasingly, attention of the optical changes has been focused extending from the near infrared (NIR; e.g., 800-2000 nm) through the microwave regions of the spectrum, which could be exploitable for optical communication, data storage, and environmental control (heat gain or loss) in buildings. ${ }^{4}$ Therefore, NIR electrochromic materials including transition metal oxides (WO3), organic metal complex (ruthenium dendrimer), and quinone-containing organic materials have been investigated in recent years. ${ }^{5}$ For organic materials, $N, N, N^{\prime}, N^{\prime}$-tetraphenyl- $p$-phenylenediamine (TPPA)-containing molecule is a interesting anodic electrochromic system for NIR applications due to its particular intramolecular electron transfer (ET) in the oxidized states.

Intramolecular ET processes were studied extensively in the mixed-valence (MV) systems ${ }^{6}$ and usually used one-dimensional MV compounds contain two or more redox states connected via $\sigma$ - or $\pi$-bridge molecule. According to Robin and Day, ${ }^{7}$ the TPPA cation radical has been reported as a symmetrical delocalized Class III structure with a strong electronic coupling (the electron is delocalized over the two redox centers), leading an intervalence charge transfer (IV-CT) absorption band in the NIR region. ${ }^{8}$

Triarylamine derivatives are well known as its photo- and electro-active properties that have potentials for optoelectronic applications, such as photoconductors, hole-transporters, lightemitters, and memory devices. ${ }^{9}$ Electron-rich triarylamines can be easily oxidized to form stable radical cations, and the oxidation process is always associated with a noticeable change of coloration. Thus, investigations of the synthesis and electrochromism of triarylamine-based polymers have been reported in the literature. ${ }^{10}$ In 2005, our groups have initiated several high-performance polymers (e.g., aromatic polyamides and polyimides) utilizing the triarylamine unit as an electrochromic functional moiety. ${ }^{11}$ In our continuous effort to develop triphenylamine (TPA)-based electrochromic high-performance polymers, ${ }^{12}$ they showed good electrochromic reversibility in the visible and NIR regions. However, most of the polymers studied so far mainly reveal green and blue electrochromic behaviors. According to the previous reports, polyimides can undergo reversible electrochemical reduction reactions with strong absorbances in the visible spectral region at the stable reduced (radical-anion and dianion) forms. ${ }^{13}$ The electroactive centers have been identified as the aromatic-carbonyl $\pi$-system of the imide functional 
groups. Hence, our strategy was to synthesize the highly stable NIR electroactive TPPA-based materials with the incorporation of strong electron-withdrawing phthalimide groups, thus could afford desirable characteristics such as excellent thermal stability, good physical properties, and the interesting electrochemical and multielectrochromic behaviors. The electroactive polymers could be obtained readily by using conventional polycondensation methods and exhibited high molecular weights. Because of the incorporation of packing-disruptive TPPA units into the polymer backbone, most of the polymers exhibited good solubility in polar organic solvents, thus transparent and flexible polymer thin films could be easily prepared by solution casting and spincoating techniques. This is useful for their fabrication of large area, thin-film electrochromic devices.

In this article, we therefore used the diamine monomer, $\mathrm{N}, \mathrm{N}$ bis(4-aminophenyl)- $N^{\prime}, N^{\prime}$-di(4-methoxyphenyl)-1,4-phenylenediamine $\left[(\mathrm{OMe})_{2}\right.$ TPPA-diamine; I] to prepare a series of aromatic poly(amine-amide-imide)s (PAAIs) containing electroactive TPPA units with para-substituted methoxy groups. The incorporation of electron-donating substituents is expected to reduce the oxidation potential associated with increased electrochemical and electrochromic stability of the resulted polymers. ${ }^{14}$ Replacement of polyimides by copolyimides such as PAAIs may be useful in modifying the intractable character of polyimides. Because of the combination of both amide and imide groups in polymer repeating units, PAAIs have structural and physical similarity between polyamides and polyimides; correspondingly, these polymers offer a good compromise between high-thermal property and processability. Thus, we anticipated that the prepared electroactive PAAIs would reveal multielectrochrmic behaviors, high-electrochemical stability, improved optical response times, and enhanced contrast of optical transmittance in NIR region. For a comparative study, some properties of the present PAAIs will be compared with those of structurally related one based on $N, N^{\prime}$-bis(4-aminophenyl)- $N, N^{\prime}$-diphenyl-1,4-phenylenediamine [TPPA-diamine; I'] that has been reported previously. ${ }^{11(a)}$
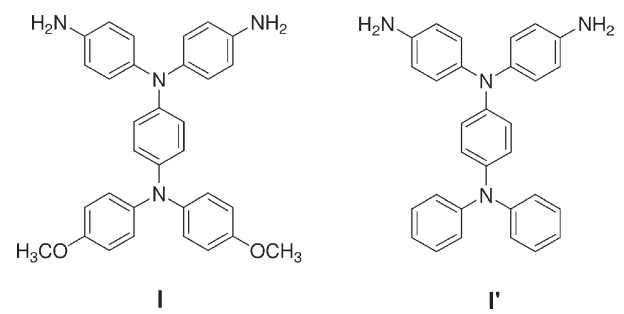

\section{EXPERIMENTAL}

\section{Materials}

A (OMe) ${ }_{2}$ TPPA-containing aromatic diamine, $N, N$-bis(4-aminophenyl)- $N^{\prime}, N^{\prime}$-di(4-methoxyphenyl)-1,4-phenylenediamine (I), was synthesized by the cesium fluoride-mediated condensation of 4-amino-4',4" -dimethoxytriphenylamine with 4-fluoronitrobenzene, followed by palladium-catalyzed hydrazine reduction of the dinitro intermediate according to a previously reported procedure. $^{14(\mathrm{~b})} 2,5$-Bis(trimellitimido)toluene ${ }^{15}$ (II-M), 1,4-bis (trimellitimido)-2,5-dimethylbenzene ${ }^{16}$ (II-2M), and 1,4-bis(tri- mellitimido)-2,5-dichlorobenzene ${ }^{17}$ (II-2Cl) were prepared as previously reported procedures. Tetrabutylammonium perchlorate (TBAP) (ACROS) was recrystallized twice from ethyl acetate and then dried in vacuo before use. All other reagents were used as received from commercial sources.

\section{Polymer Synthesis}

The synthesis of poly(amine-amide-imide) PAAI-2M was used as an example to illustrate the general synthetic route used to produce the PAAIs. A mixture of $0.5026 \mathrm{~g}(1.00 \mathrm{mmol})$ of the diamine monomer I, $0.4703 \mathrm{~g}(1.00 \mathrm{mmol})$ of 1,4-bis(trimellitimido)-2,5-dimethylbenzene (II-2M), $0.12 \mathrm{~g}$ of calcium chloride, $1.00 \mathrm{~mL}$ of triphenyl phosphite (TPP), $0.50 \mathrm{~mL}$ of pyridine, and $1.00 \mathrm{~mL}$ of $\mathrm{N}$-methyl-2-pyrrolidinone (NMP) was heated with stirring at $105{ }^{\circ} \mathrm{C}$ for $3 \mathrm{~h}$. The obtained polymer solution was poured slowly into $300 \mathrm{~mL}$ of stirred methanol giving rise to a stringy, fiber-like precipitate that was collected by filtration, washed thoroughly with hot water and methanol, and dried under vacuum at $100{ }^{\circ} \mathrm{C}$. Reprecipitations of the polymer by $\mathrm{N}, \mathrm{N}$ dimethylacetamide (DMAc)/methanol were carried out twice for further purification. The inherent viscosity and weight-average molecular weights $\left(M_{\mathrm{w}}\right)$ of the obtained polymer PAAI-2M were $0.53 \mathrm{dL} / \mathrm{g}$ (measured at a concentration of $0.5 \mathrm{~g} / \mathrm{dL}$ in DMAc at $30{ }^{\circ} \mathrm{C}$ ) and 93,500 Da, respectively. The Fourier transform infrared (FTIR) spectrum of PAAI-2M (film) exhibited characteristic amide absorption bands at $3372 \mathrm{~cm}^{-1}$ (N-H stretch), 1660 $\mathrm{cm}^{-1}$ (amide carbonyl), imide absorption bands at $1778 \mathrm{~cm}^{-1}$ (asymmetrical $\mathrm{C}=0$ ), $1724 \mathrm{~cm}^{-1}$ (symmetrical $\mathrm{C}=0$ ), 1357 $\mathrm{cm}^{-1}(\mathrm{C}-\mathrm{N})$, and $725 \mathrm{~cm}^{-1}$ (imide ring deformation).

${ }^{1} \mathrm{H}$ NMR (DMSO- $d_{6}, \delta, \mathrm{ppm}$ ): $2.17\left(\mathrm{~s}, 6 \mathrm{H}, \mathrm{CH}_{3}\right.$ ), $3.73(\mathrm{~s}, 6 \mathrm{H}$, $\left.\mathrm{OCH}_{3}\right), 6.80\left(\mathrm{~d}, 2 \mathrm{H}, \mathrm{H}_{\mathrm{c}}\right), 6.90\left(\mathrm{~d}, 4 \mathrm{H}, \mathrm{H}_{\mathrm{f}}\right), 6.93\left(\mathrm{~d}, 2 \mathrm{H}, \mathrm{H}_{\mathrm{d}}\right), 7.01$ (d, 4H, $\mathrm{H}_{\mathrm{e}}$ ), $7.03\left(\mathrm{~d}, 4 \mathrm{H}, \mathrm{H}_{\mathrm{b}}\right), 7.49\left(\mathrm{~s}, 2 \mathrm{H}, \mathrm{H}_{\mathrm{j}}\right), 7.75\left(\mathrm{~d}, 4 \mathrm{H}, \mathrm{H}_{\mathrm{a}}\right)$, $8.16\left(\mathrm{~d}, 2 \mathrm{H}, \mathrm{H}_{\mathrm{h}}\right), 8.47$ (d, $\left.2 \mathrm{H}, \mathrm{H}_{\mathrm{g}}\right), 8.58\left(\mathrm{~s}, 2 \mathrm{H}, \mathrm{H}_{\mathrm{i}}\right), 10.60(\mathrm{~s}, 2 \mathrm{H}$, $\mathrm{NH}-\mathrm{CO}) .{ }^{13} \mathrm{C}$ NMR (DMSO- $\left.d_{6}, \delta, \mathrm{ppm}\right): 17.0\left(\mathrm{CH}_{3}\right), 55.1$ $\left(\mathrm{OCH}_{3}\right), 114.8,121.5,121.7,122.2,123.0,123.8,125.2,125.7$, $125.9,131.1,131.4,131.8,133.3,133.7,134.3,134.8,140.1$, 140.4, 143.7, 143.9, 155.3, 163.1 (NH-CO), 166.2, 166.4. Anal. Calcd. for $\mathrm{C}_{58} \mathrm{H}_{42} \mathrm{~N}_{6} \mathrm{O}_{8}$ (950.99): C, 73.25\%; $\mathrm{H}, 4.45 \%$; $\mathrm{N}$, 8.84\%. Found: C, 68.07\%; H, 5.48\%; N, 8.27\%.

The fourier transform infrared (FT-IR) and ${ }^{1} \mathrm{H}$ NMR spectra of PAAI-2M are shown in Supporting Information (see Figs. S1 and S2). The other PAAIs were prepared by an analogous procedure (see Supporting Information Fig. S1).

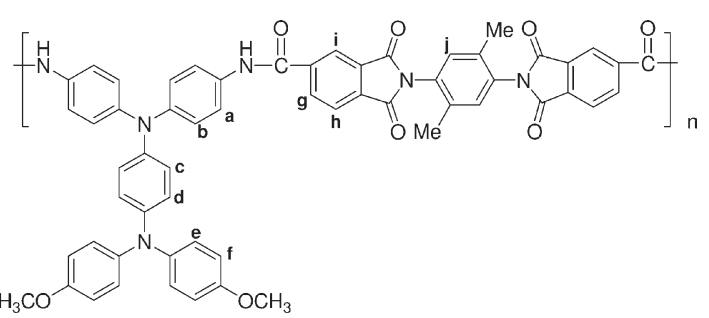

Preparation of the Poly(amine-amide-imide) Films

A solution of polymer was made by dissolving about $0.7 \mathrm{~g}$ of the PAAI sample in $10 \mathrm{~mL}$ of DMAc. The homogeneous solution was poured into a 9-cm glass Petri dish, which was placed in a $90{ }^{\circ} \mathrm{C}$ oven for $2 \mathrm{~h}$ to remove most of the solvent; then the semidried film was further dried in vacuo at 
<smiles>COc1ccc(N(c2ccc(OC)cc2)c2ccc(N(c3ccc(N)cc3)c3ccc(N)cc3)cc2)cc1</smiles>

I<smiles>O=C(O)c1ccc2c(c1)C(=O)N([Ga]N1C(=O)c3ccc(C(=O)O)cc3C1=O)C2=O</smiles>

II

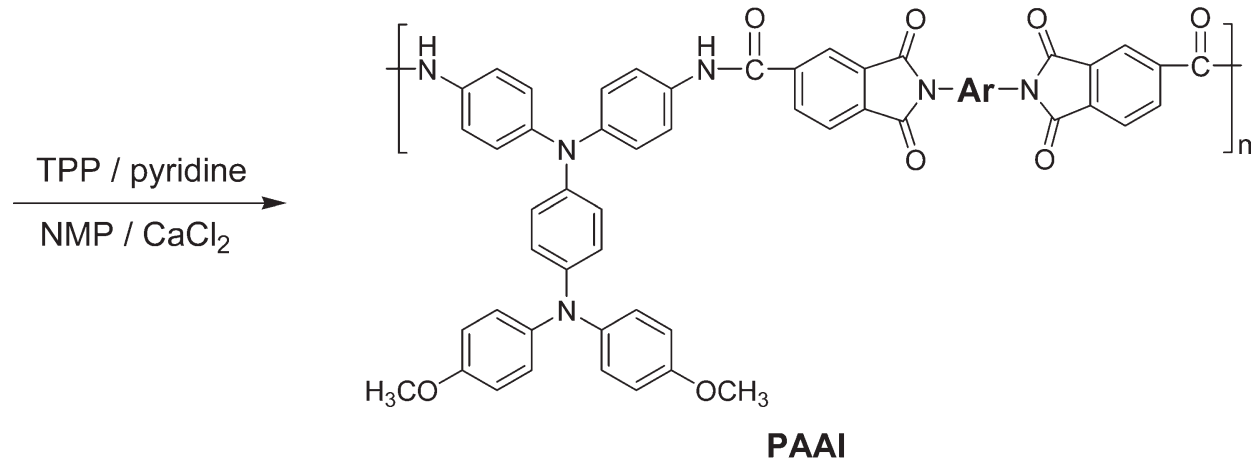

Ar:

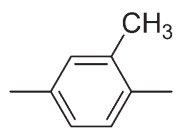

SCHEME 1 Synthesis of poly (amine-amide-imide)s.

$160{ }^{\circ} \mathrm{C}$ for $8 \mathrm{~h}$. The obtained films were about $50-75 \mu \mathrm{m}$ in thickness and were used for solubility tests and thermal analyses.

\section{Measurements}

FTIR spectra were recorded on a PerkinElmer Spectrum 100 Model FTIR spectrometer. ${ }^{1} \mathrm{H}$ and ${ }^{13} \mathrm{C}$ NMR spectra were measured on a Bruker $\mathrm{AC}-300 \mathrm{MHz}$ spectrometer in deuterated dimethyl sulfoxide (DMSO- $d_{6}$ ), using tetramethylsilane as an internal reference, and peak multiplicity was reported as follows: s, singlet; d, doublet. Elemental analyses were run in a Heraeus VarioEL-III CHNS elemental analyzer. The inherent viscosities were determined at $0.5 \mathrm{~g} / \mathrm{dL}$ concentration using Tamson TV-2000 viscometer at $30{ }^{\circ} \mathrm{C}$. Gel permeation chromatographic analysis was carried out on a Waters chromatography unit interfaced with a Waters 2410 refractive index detector. Two Waters $5 \mu \mathrm{m}$ Styragel HR-2 and HR4 columns (7.8 mm I.D. $\times 300 \mathrm{~mm}$ ) were connected in series with NMP as the eluent at a flow rate of $0.5 \mathrm{~mL} / \mathrm{min}$ at 60 ${ }^{\circ} \mathrm{C}$ and were calibrated with polystyrene standards. Thermogravimetric analysis (TGA) was conducted with a Perkin

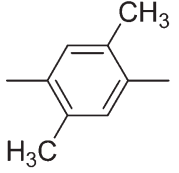

$2 \mathrm{M}$

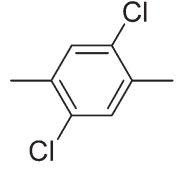

$2 \mathrm{Cl}$
Elmer Pyris 1 TGA. Experiments were carried out on $\sim 6-8$ mg film samples heated in flowing nitrogen or air (flow rate $=20 \mathrm{~cm}^{3} / \mathrm{min}$ ) at a heating rate of $20{ }^{\circ} \mathrm{C} / \mathrm{min}$. Differential scanning calorimetry (DSC) analyses were performed on a PerkinElmer Pyris 1 DSC at a scan rate of $20^{\circ} \mathrm{C} / \mathrm{min}$ in flowing nitrogen $\left(20 \mathrm{~cm}^{3} / \mathrm{min}\right)$. Electrochemistry was performed with a $\mathrm{CH}$ Instruments 611B electrochemical analyzer. Voltammograms are presented with the positive potential pointing to the left and with increasing anodic currents pointing downward. Cyclic voltammetry (CV) was conducted with the use of a three-electrode cell in which indium tin oxide (ITO) (polymer films area about $0.5 \mathrm{~cm} \times 1.1 \mathrm{~cm}$ ) was used as a working electrode. A platinum wire was used as an auxiliary electrode. All cell potentials were taken by using a homemade $\mathrm{Ag} / \mathrm{AgCl}, \mathrm{KCl}$ (sat.) reference electrode. Ferrocene was used as an external reference for calibration [0.44 V vs. Ag/ $\mathrm{AgCl}$ in $\mathrm{CH}_{3} \mathrm{CN}$; $0.52 \mathrm{~V}$ vs. $\mathrm{Ag} / \mathrm{AgCl}$ in dimethylformamide (DMF)]. Spectroelectrochemical experiments were carried out in a cell built from a $1 \mathrm{~cm}$ commercial ultraviolet (UV)visible cuvette using Hewlett-Packard 8453 UV-Visible diode array UV-vis-NIR spectrophotometer. The ITO-coated glass 
TABLE 1 Thermal Properties of Poly(amine-amide-imide)s

\begin{tabular}{|c|c|c|c|c|c|c|}
\hline \multirow[b]{2}{*}{ Polymer Code } & \multirow[b]{2}{*}{$T_{\mathrm{g}}\left({ }^{\circ} \mathrm{C}\right)^{\mathrm{a}}$} & \multicolumn{2}{|c|}{$\begin{array}{c}T_{\mathrm{d}} \text { at } 5 \% \text { Weight } \\
\text { Loss }\left({ }^{\circ} \mathrm{C}\right)^{\mathrm{b}}\end{array}$} & \multicolumn{2}{|c|}{$\begin{array}{c}T_{\mathrm{d}} \text { at } 10 \% \text { Weight } \\
\text { Loss }\left({ }^{\circ} \mathrm{C}\right)^{\mathrm{b}}\end{array}$} & \multirow[b]{2}{*}{ Char Yield (wt \%) } \\
\hline & & $\mathrm{N}_{2}$ & Air & $\mathrm{N}_{2}$ & Air & \\
\hline PAAI-M & 288 & 490 & 485 & 520 & 535 & 60 \\
\hline PAAI-2M & 314 & 485 & 480 & 520 & 530 & 63 \\
\hline PAAI-2CI & 302 & 475 & 480 & 510 & 515 & 62 \\
\hline
\end{tabular}

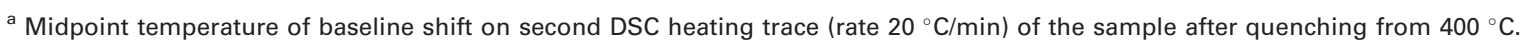

b Decomposition temperature, recorded via TGA at a heating rate of $20{ }^{\circ} \mathrm{C} / \mathrm{min}$ and a gas-flow rate of $20 \mathrm{~cm} / \mathrm{min}$.

${ }^{\mathrm{c}}$ Residual weight percentage at $800{ }^{\circ} \mathrm{C}$ in nitrogen.

slide was used as the working electrode, a platinum wire as the counter electrode, and an $\mathrm{Ag} / \mathrm{AgCl}$ cell as the reference electrode. Coloration efficiency (CE) $(\eta)$ determines the amount of optical density change ( $\delta O D)$ at a specific absorption wavelength induced as a function of the injected/ejected charge $(Q$; also termed as electroactivity), which is determined from the in situ experiments. $\mathrm{CE}$ is given by the equation: $\eta=\delta \mathrm{OD} / Q=\log \left[T_{\mathrm{b}} / T_{\mathrm{c}}\right] / Q$, where $\eta\left(\mathrm{cm}^{2} / \mathrm{C}\right)$ is the CE at a given wavelength, and $T_{\mathrm{b}}$ and $T_{\mathrm{c}}$ are the bleached and colored transmittance values, respectively. The thickness of the PAAI thin films was measured by alpha-step profilometer (Kosaka Lab., Surfcorder ET3000, Japan).

\section{RESULTS AND DISCUSSION}

\section{Polymer Synthesis}

According to the phosphorylation polyamidation technique described by Yamazaki, ${ }^{18}$ a series of novel $(\mathrm{OMe})_{2}$ TPPAbased PAAIs were synthesized from the polycondensation reactions of diamine monomer I with three aromatic diimide-diacids II by using TPP and pyridine as condensing agents (Scheme 1). All polymerization reactions proceeded homogenously and gave high-viscous polymer solution, which precipitated in a tough, fiber-like form when the resulting polymer solutions were slowly poured into stirring methanol. The obtained PAAIs had inherent viscosities in the range of $0.28-0.61 \mathrm{dL} / \mathrm{g}$ with weight-average molecular weights $\left(M_{\mathrm{w}}\right)$ and polydispersity of 84,900-103,100 Da and 1.75-2.18, respectively, relative to polystyrene standards as summarized in Supporting Information Tables S1 and S2. All the polymers can be solution-cast into flexible and transparent films, indicating the formation of high molecular weight polymers. The structures of the PAAIs were confirmed by IR spectroscopy. As shown in Supporting Information Figure S1, a typical IR spectrum for PAAI-2M exhibited characteristic absorption bands of the amide group at around $3372 \mathrm{~cm}^{-1}$ (N-H stretch) and $1660 \mathrm{~cm}^{-1}$ (amide carbonyl), and the characteristic imide absorption bands at 1778 (asymmetrical $\mathrm{C}=0$ ), 1724 (symmetrical $\mathrm{C}=0$ ), $1357\left(\mathrm{C}-\mathrm{N}\right.$ ), and $725 \mathrm{~cm}^{-1}$ (imide ring deformation). Supporting Information Figure S2 shows a typical ${ }^{1} \mathrm{H}$ NMR spectrum of PAAI-2M in DMSO- $d_{6}$, where all peaks have been assigned to the hydrogen atoms, and the spectra agree well with the proposed molecular structure of PAAI-2M. A structurally related PAAI-2M' derived from diamine $\mathbf{I}^{\prime}$ is used for comparison studies. The synthesis and characterization of polymer PAAI-2 $\mathbf{M}^{\prime}$ has been described previously. ${ }^{19}$

\section{Solubility and Film Property}

The solubility properties of polymers were investigated qualitatively, and the results are also listed in Supporting Information Table S1. Most of the PAAIs were readily soluble in polar aprotic organic solvents such as NMP, DMAc, and dimethyl sulfoxide (DMSO) at room temperature and formed flexible, tough, and transparent films by solution casting. Their high solubility and amorphous properties can be attributed to the incorporation of bulky, three-dimensional $(\mathrm{OMe})_{2}$ TPPA moiety along the polymer backbone, which results in a high steric hindrance for close packing, and thus reduces their crystallization tendency. Therefore, the excellent solubility makes these polymers as potential candidates for practical applications by spin-coating or inkjet-printing processes to afford high-performance thin films for optoelectronic devices.

\section{Thermal Properties}

The thermal properties of PAAIs were investigated by TGA and DSC, and the thermal behavior data are summarized in Table 1. Typical TGA curves of representative polymer PAAI-

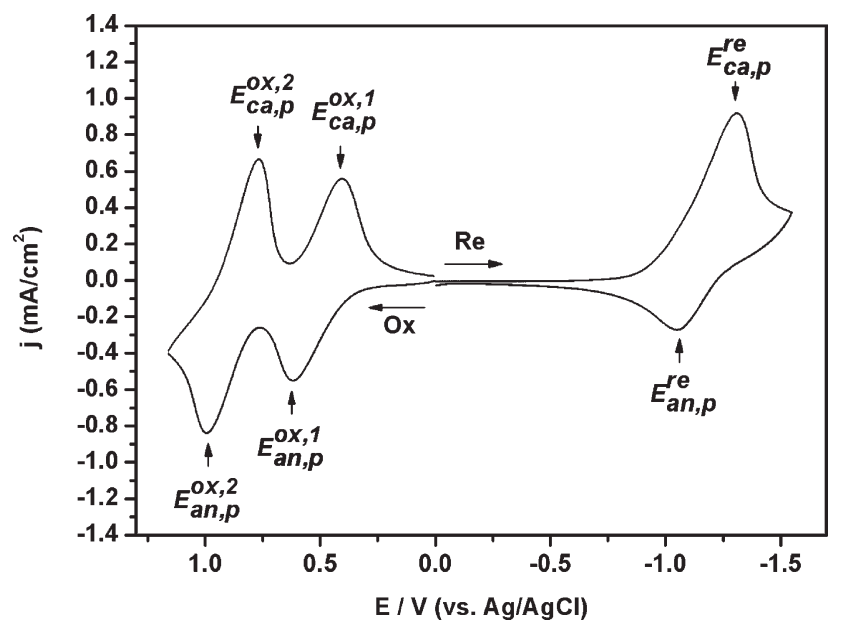

FIGURE 1 Cyclic voltammetric diagram of PAAI-2M film on ITO-coated glass substrate in $\mathrm{CH}_{3} \mathrm{CN}$ (oxidation) and DMF (reduction) solutions containing $0.1 \mathrm{M}$ TBAP at scan rate of 50 and $100 \mathrm{mV} / \mathrm{s}$, respectively. 
(a)

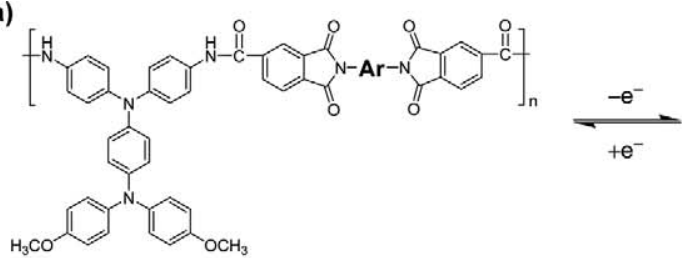

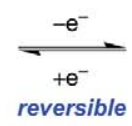

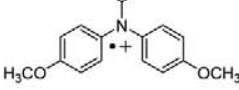
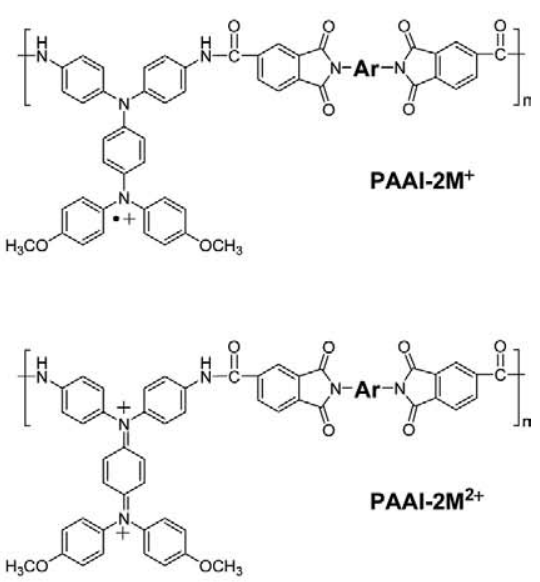

(b)
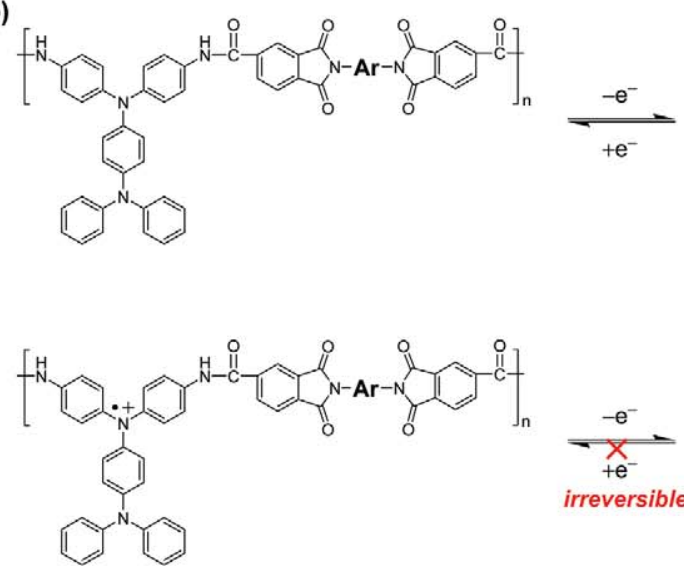
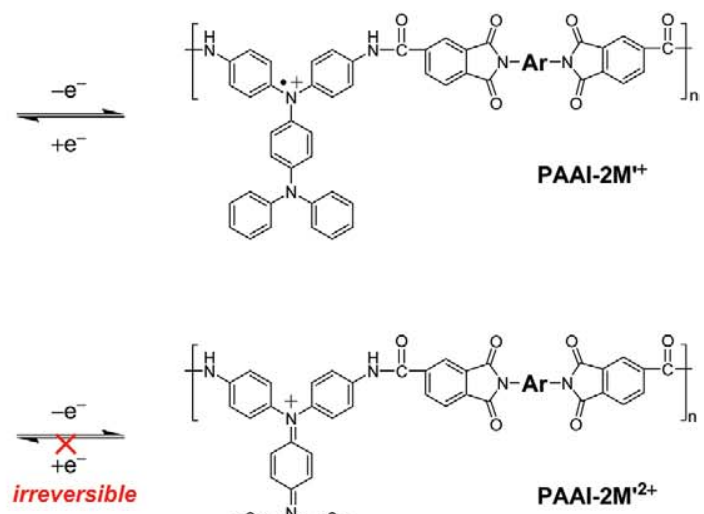

AAI-2M ${ }^{2+}$

SCHEME 2 The anodic oxidation pathways of poly(amine-amideimide)s PAAI-2M and PAAI-2M'. [Color figure can be viewed in the online issue, which is available at wileyonlinelibrary.com.]

2M in both air and nitrogen atmospheres are shown in Supporting Information Figure S3. All the prepared PAAIs exhibited good thermal stability with insignificant weight loss up to $400{ }^{\circ} \mathrm{C}$ in nitrogen. The $10 \%$ weight loss temperatures of these polymers in nitrogen and air were recorded in the range of $510-520{ }^{\circ} \mathrm{C}$ and $515-535{ }^{\circ} \mathrm{C}$, respectively. The amount of carbonized residue (char yield) of these polymers in a nitrogen atmosphere was more than $60 \%$ at $800{ }^{\circ} \mathrm{C}$. The high-char yields of these polymers can be ascribed to their high-aromatic content. The glass-transition temperatures $\left(T_{\mathrm{g}}\right)$ of PAAIs could be easily measured in the DSC thermograms; they were observed in the range of $288-314{ }^{\circ} \mathrm{C}$ (as shown in Supporting Information Fig. S4). The lowest $T_{\mathrm{g}}$ value of PAAI-M in this se-

ries polymers can be explained in terms of less steric hindrance in its diimide-diacid component. All the polymers indicated no clear melting endotherms up to the decomposition temperatures on the DSC thermograms, which supports the amorphous nature of these PAAIs.

\section{Electrochemical Properties}

The electrochemical properties of the PAAIs were investigated by $\mathrm{CV}$ conducted for the cast film on an ITO-coated glass substrate as working electrode. The oxidation and reduction cycles of the film samples were measured in acetonitrile $\left(\mathrm{CH}_{3} \mathrm{CN}\right)$ and DMF, respectively, using $0.1 \mathrm{M}$ of TBAP as a supporting electrolyte under a nitrogen atmosphere for 

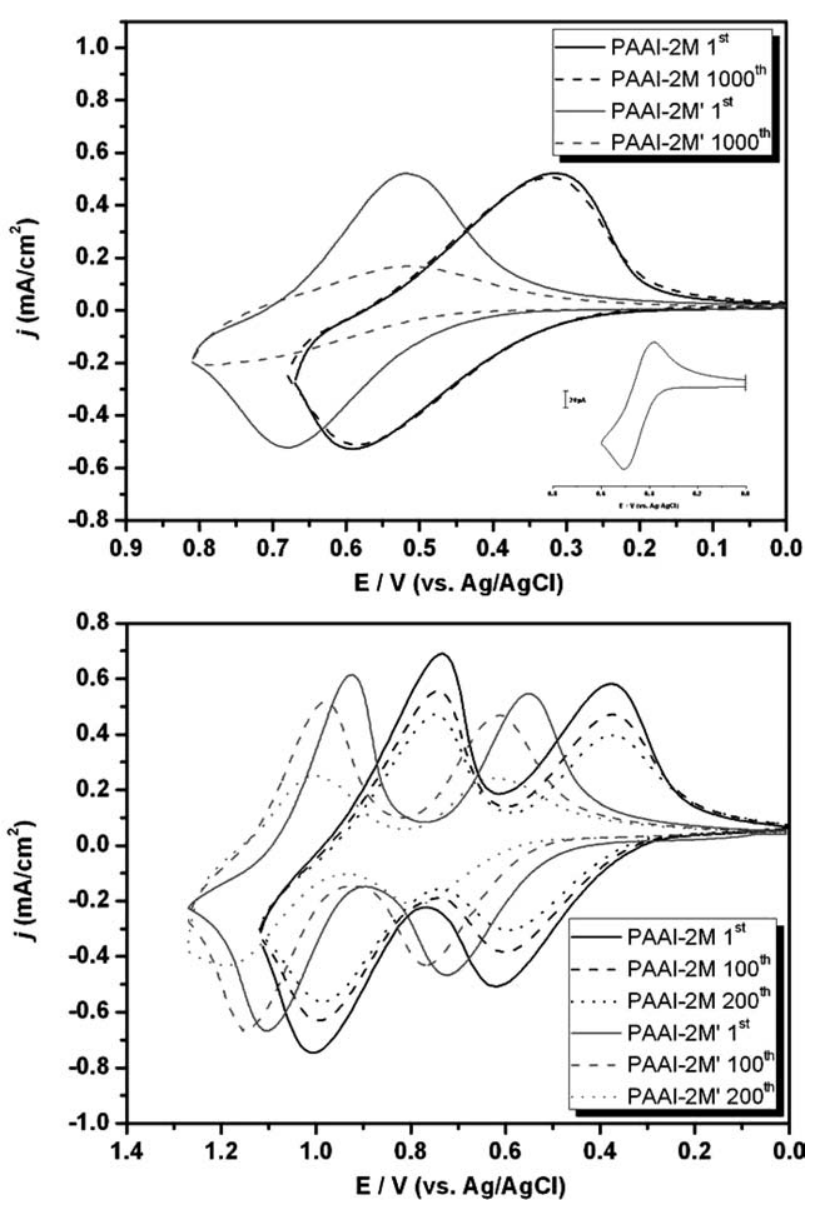

FIGURE 2 Cyclic voltammetric diagrams of poly(amine-amideimide) PAAI-2M and PAAI-2 $\mathbf{M}^{\prime}$ films on an ITO-coated glass substrate over cyclic scans and ferrocene (inset) in $0.1 \mathrm{M}$ $\mathrm{TBAP} / \mathrm{CH}_{3} \mathrm{CN}$ at a scan rate of $50 \mathrm{mV} / \mathrm{s}$.

oxidation and reduction measurements. Typical CV curves of PAAI-2M are shown in Figure 1. All the PAAIs exhibited two reversible oxidation and one reduction processes (see Supporting Information Fig. S5), revealing their high-electrochemical stability for both $p$ - and $n$-doping (ambipolar) process, and these results are similar to the previous reports of ambipolar polymers. ${ }^{20}$ These reversible oxidation redox waves represent the formation of stable radical cation and radical dication originating from electrochemical redox reactions of the (OMe) ${ }_{2}$ TPPA [Scheme 2(a)]. To understand the reduction redox properties of PAAIs, we choose the simplest structure of polyimide, Kapton ${ }^{\circledR}$ to undergo electrochemical reduction. The representative cyclic voltammogram for Kapton $^{\circledR}$ is shown in Supporting Information Figure S6. The pyromellitimide segment undergoes two reversible ETs with the first reduced step at the half-wave potential $\left(E_{1 / 2}\right)$ of $-0.83 \mathrm{~V}$ corresponding to reduction of the neutral form to the radical anion, and the second reduced couple at $-1.34 \mathrm{~V}$ relates to further reduction of the radical anion to the dianion state. ${ }^{13}$ The redox mechanism associated with the reduction of Kapton ${ }^{\circledR}$ has been proposed (Supporting Information Scheme S1). ${ }^{13(a)}$ The observed electrochemical reduction of the PAAIs are similar to the previous report, ${ }^{21}$ confirming the imide's carbonyl group as the electroactive site.

The typical CV for polymer PAAI-2M (with 4,4'-dimethoxy-substituted) and PAAI-2M' (without 4,4'-dimethoxy-substituted) is shown in Figure 2 for comparison; there are two reversible oxidation redox couples at the half-wave potential $\left(E_{1 / 2}\right)$ of $0.51 \mathrm{~V}$ $\left(E_{\text {onset }}=0.36\right)$ and $0.87 \mathrm{~V}$ for PAAI-2M, $0.64\left(E_{\text {onset }}=0.51\right)$ and $1.01 \mathrm{~V}$ for PAAI-2 $\mathbf{M}^{\prime}$ in the oxidative scan, respectively. When comparing the electrochemical data, it was found that PAAI-2M is more easily oxidized than PAAI-2M'. Obviously, the lower oxidation potential of PAAI-2M compared with its analog PAAI-2 $\mathbf{M}^{\prime}$ can be attributed to the para-position substituted electrondonating methoxy group on TPPA groups. During the electrochemical oxidation of the PAAI thin films, the color of the film changed from pale yellow to green and then to blue. Because of the high-electrochemistry stability, PAAI-2M exhibited reversible CV behavior by continuous 1000 cyclic and 200 cyclic scans in the first- and second-oxidation stages, respectively. On the con-

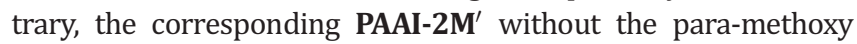
substituted on TPPA units gradually lost redox reversibility after several CV scans. This result also confirms that para-substitution of the methoxy group on the TPPA unit effectively increases stability for both the cation radical and dication quinonediimine species. According to these results, mechanisms of oxidation reactions for PAAI-2M and PAAI-2M' $\mathbf{M}^{\prime}$ are proposed in Scheme 2. The redox potentials of the PAAIs and their respective highest occupied molecular orbital and lowest unoccupied molecular orbital (vs. vacuum) are shown in Table 2.

TABLE 2 Redox Potentials and Energy Levels of Poly(amine-amide-imide)s

\begin{tabular}{|c|c|c|c|c|c|c|c|c|c|c|c|c|}
\hline \multirow[b]{2}{*}{ Polymer } & \multirow{2}{*}{$\begin{array}{c}\text { Thin Films } \\
\lambda_{\text {onset }}\end{array}$} & \multicolumn{3}{|c|}{ Oxidation ${ }^{a}$} & \multicolumn{2}{|c|}{ Reduction $^{\mathrm{b}}$} & \multirow[b]{2}{*}{$E_{\mathrm{g}}^{\mathrm{Opt}}(\mathrm{eV})$} & \multicolumn{2}{|c|}{ Oxidation } & \multicolumn{2}{|c|}{ Reduction } & \multirow[b]{2}{*}{$E_{\mathrm{g}}^{\mathrm{EC}}(\mathrm{eV})$} \\
\hline & & $E_{\text {onset }}$ & $E_{1 / 2(\mathrm{ox} 1)}$ & $E_{1 / 2(\mathrm{ox} 2)}$ & $E_{\text {onset }}$ & $E_{1 / 2}$ & & $\mathrm{HOMO}^{\mathrm{c}}$ & LUMO $^{d}$ & $\mathrm{HOMO}^{\mathrm{e}}$ & LUMO $^{f}$ & \\
\hline PAAI-M & 571 & 0.39 & 0.52 & 0.89 & -0.85 & -1.15 & 2.17 & 4.88 & 2.71 & 5.30 & 3.13 & 1.93 \\
\hline PAAI-2M & 583 & 0.36 & 0.51 & 0.87 & -0.87 & -1.18 & 2.12 & 4.87 & 2.75 & 5.22 & 3.10 & 1.92 \\
\hline PAAI-2CI & 566 & 0.42 & 0.54 & 0.90 & -0.81 & -1.13 & 2.19 & 4.90 & 2.71 & 5.34 & 3.15 & 1.93 \\
\hline
\end{tabular}

a From cyclic votammograms versus $\mathrm{Ag} / \mathrm{AgCl}$ in $\mathrm{CH}_{3} \mathrm{CN}$. $E_{1 / 2}$ : Average potential of the redox couple peaks.

${ }^{\mathrm{b}}$ From cyclic votammograms versus $\mathrm{Ag} / \mathrm{AgCl}$ in $\mathrm{DMF}$. $E_{\mathrm{g}}^{\mathrm{Opt}}$, optical band gap is derived from polymer films $\left(E_{\mathrm{g}}^{\mathrm{Opt}}=1240 / \lambda_{\text {onset }}\right) ; E_{\mathrm{g}}^{\mathrm{EC}}$, electrochemical band gap is derived from the difference between the $E_{a n, p}^{o x, 1}$ and $E_{\text {ca.p. }}^{\text {re }}$. c The HOMO energy levels were calculated from cyclic voltammetry and were referenced to ferrocene $\left(E_{1 / 2}=0.44 \mathrm{~V}\right)$.

${ }^{\mathrm{d}} \mathrm{LUMO}=\mathrm{HOMO}-E_{\mathrm{gpt}}^{\mathrm{Opt}}$.

${ }^{\mathrm{e}} \mathrm{HOMO}=\mathrm{LUMO}+E_{\mathrm{g}}^{\mathrm{ppt}}$.

${ }^{f}$ The LUMO energy levels were calculated from cyclic voltammetry and were referenced to ferrocene $\left(E_{1 / 2}=0.52 \mathrm{~V}\right)$. 

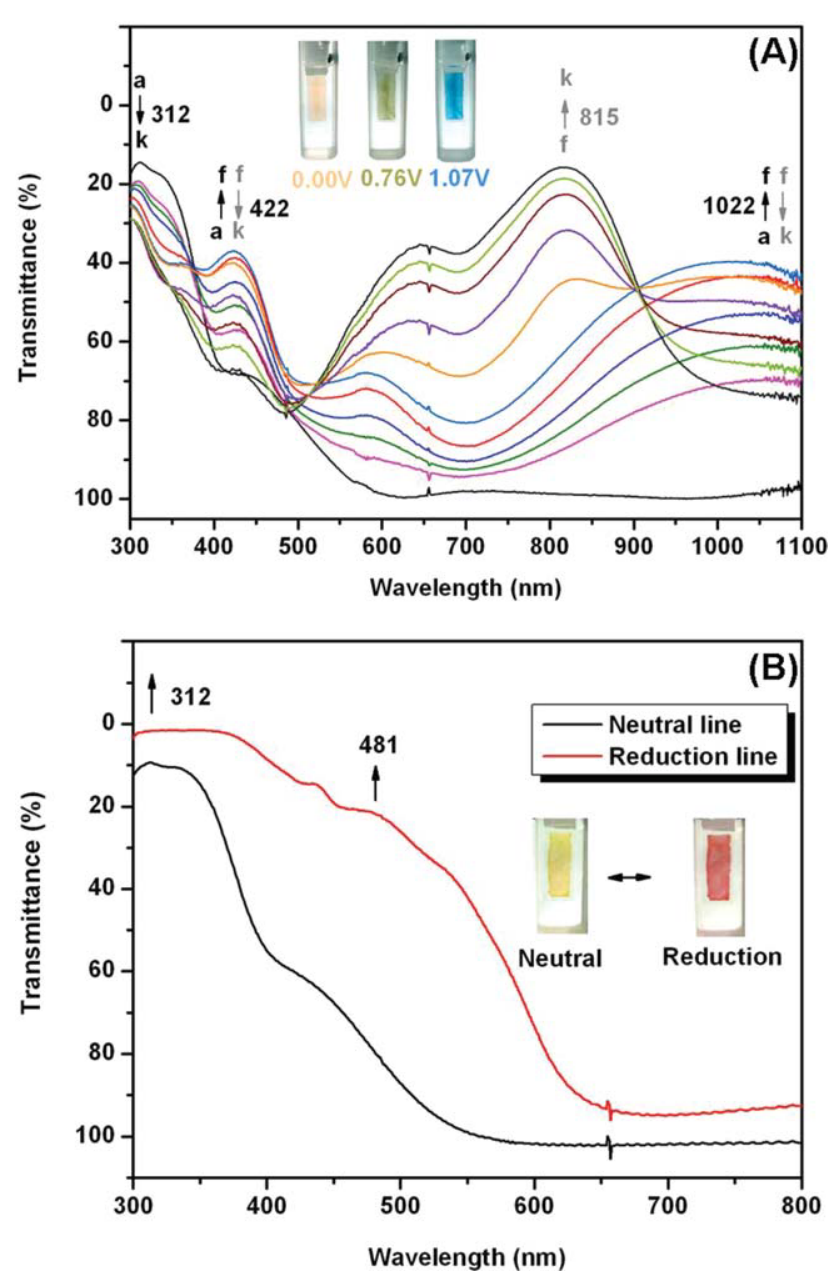

FIGURE 3 Electrochromic behavior of poly(amine-amide-imide) PAAI-2M film on the ITO-coated glass substrate in (A) 0.1 $\mathrm{M}$ TBAP $/ \mathrm{CH}_{3} \mathrm{CN}$ at applied potentials of (a) 0.00 , (b) 0.52 , (c) 0.55, (d) 0.58, (e) 0.64, (f) 0.76, (g) 0.87, (h) 0.90, (i) 0.93, (j) 0.96, and (k) $1.07 \mathrm{~V}$ (vs. $\mathrm{Ag} / \mathrm{AgCl}$ ), $\mathrm{PAAl}-2 \mathrm{M}^{+}$, black solid arrow; PAAl- $2 \mathrm{M}^{2+}$, gray solid arrow and (B) $0.1 \mathrm{M}$ TBAP/DMF at applied potentials from 0 to $-2.00 \mathrm{~V}$ (vs. $\mathrm{Ag} / \mathrm{AgCl}$ ).

\section{Spectroelectrochemistry}

Spectroelectrochemical experiments were used to evaluate the optical properties of the electrochromic films. For the investigations, the PAAI film was cast on an ITO-coated glass slide (a piece that fit in the commercial UV-visible cuvette), and a homemade electrochemical cell was built from a commercial ultraviolet (UV)-visible cuvette. The cell was placed in the optical path of the sample light beam in a UV-vis-NIR spectrophotometer, which allowed us to acquire electronic absorption spectra under potential control in a 0.1 M TBAP/ $\mathrm{CH}_{3} \mathrm{CN}$ solution for oxidation and 0.1 M TBAP/DMF solution for reduction, respectively. The result of the PAAI-2M film upon oxidation and reduction are presented in Figure 3 as a series of UV-vis-NIR absorbance curves correlated to electrode potentials. Figure 4 shows the three-dimensional \% transmittance wavelength-applied potential correlations of this sample. The PAAI-2M film exhibited strong absorption

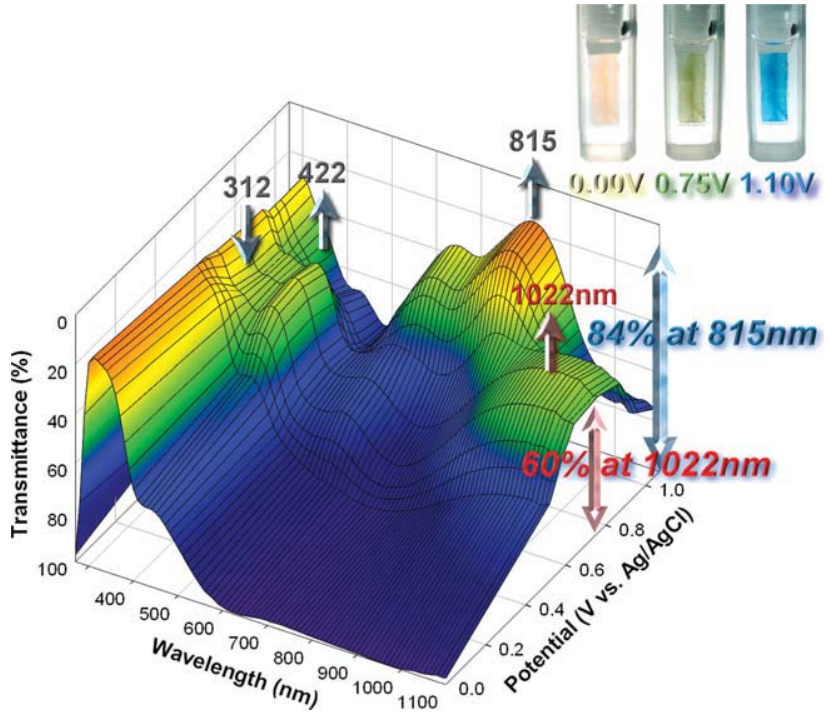

FIGURE 4 Three-dimensional spectroelectrochemical behavior of PAAI-2M thin film on the ITO-coated glass substrate in 0.1 $\mathrm{M} \mathrm{TBAP} / \mathrm{CH}_{3} \mathrm{CN}$ from 0 to $1.07 \mathrm{~V}$ (vs. $\mathrm{Ag} / \mathrm{AgCl}$ ).

at around $312 \mathrm{~nm}$, characteristic for triarylamine unit in the neutral form $(0 \mathrm{~V})$, with almost transparent at wavelengths $>600 \mathrm{~nm}$. Upon oxidation (increasing applied voltage from 0 to $0.76 \mathrm{~V}$ ), the intensity of the absorption peak at $312 \mathrm{~nm}$ gradually decreased, whereas a new peak at $422 \mathrm{~nm}$ and a

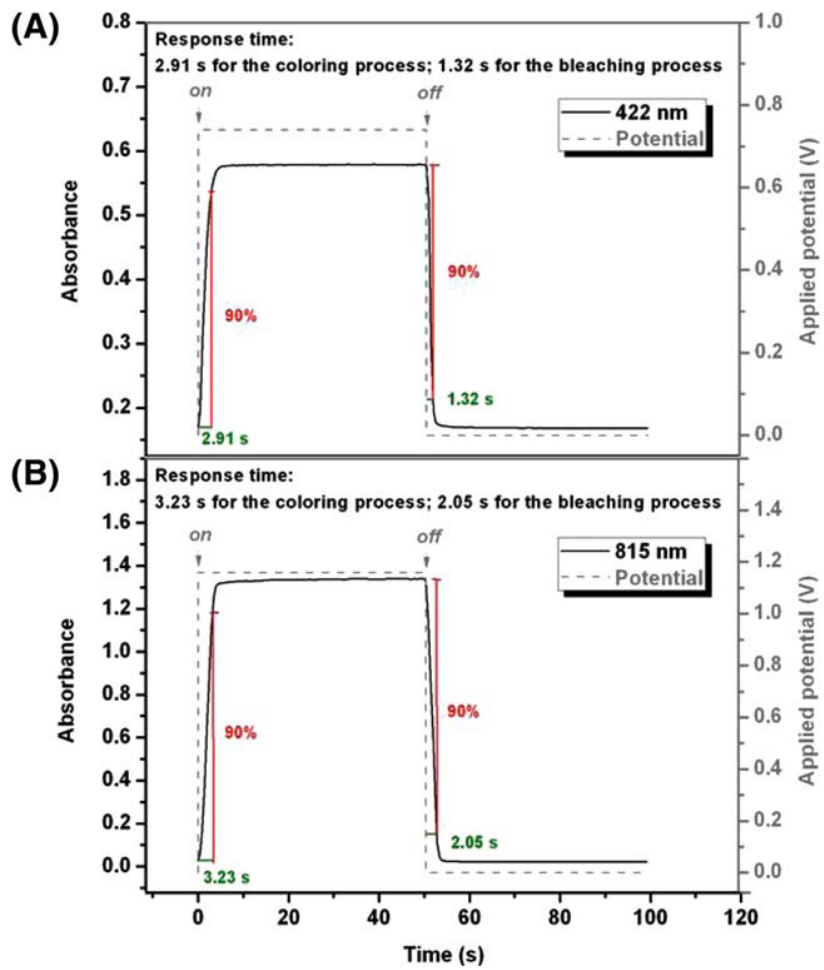

FIGURE 5 Calculation of optical switching time at (A) $422 \mathrm{~nm}$ and (B) $815 \mathrm{~nm}$ at the applied potential curves of PAAI-2M thin film ( $300 \mathrm{~nm}$ in thickness) on the ITO-coated glass substrate (coated area: $1.1 \mathrm{~cm} \times 0.5 \mathrm{~cm}$ ) in $0.1 \mathrm{M} \mathrm{TBAP} / \mathrm{CH}_{3} \mathrm{CN}$. 

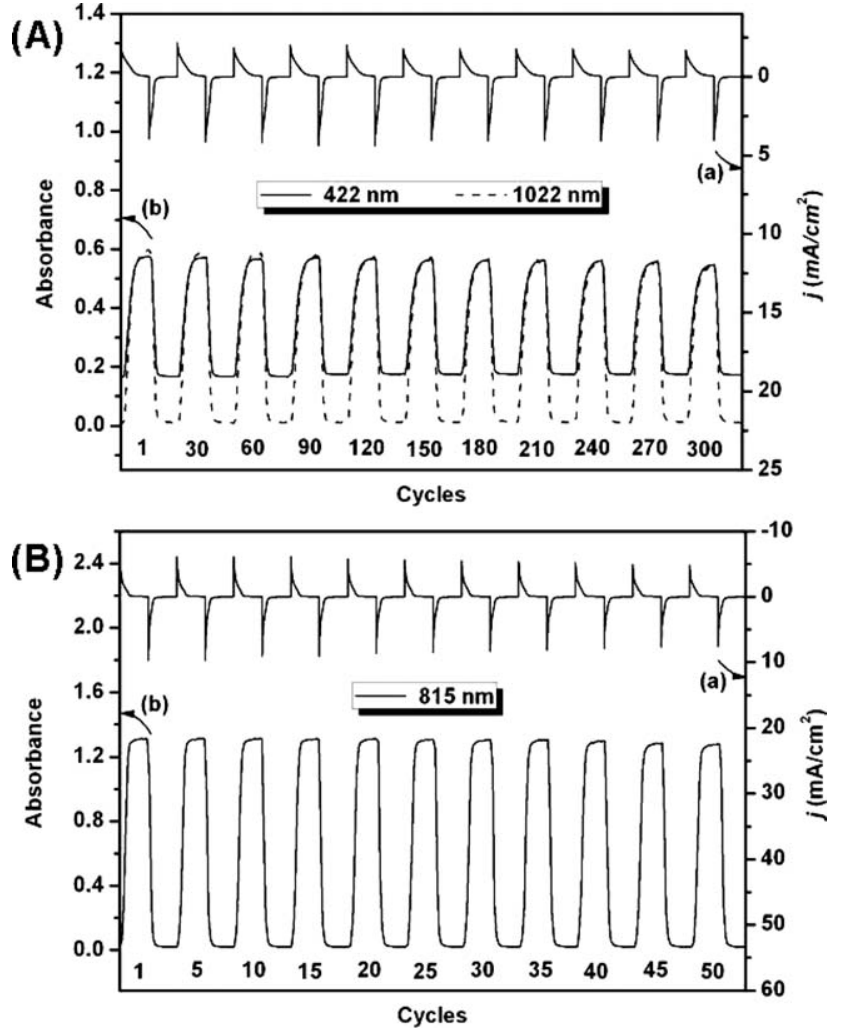

FIGURE 6 Electrochromic switching between (A) 0 and $0.74 \mathrm{~V}$ and $(\mathrm{B}) 0$ and $1.16 \mathrm{~V}$ (vs. $\mathrm{Ag} / \mathrm{AgCl})$ of PAAl-2M thin film ( 300 $\mathrm{nm}$ in thickness) on the ITO-coated glass substrate (coated area: $1.1 \mathrm{~cm} \times 0.5 \mathrm{~cm}$ ) in $0.1 \mathrm{M} \mathrm{TBAP} / \mathrm{CH}_{3} \mathrm{CN}$ with a cycle time of $14 \mathrm{~s}$. (a) Current consumption and (b) absorbance change monitored at the given wavelength.

broad band having its maximum absorption wavelength at $1022 \mathrm{~nm}$ in the NIR region gradually increased in intensity. We attribute this spectral change in visible range to the formation of a stable monocation radical of the TPA center in TPPA moiety. Furthermore, the broad absorption in NIR region was the characteristic result due to IV-CT excitation associated with ET from active neutral nitrogen atom to the cation radical nitrogen center of TPPA moiety, which was consistent with the phenomenon classified by Robin and Day. $^{7}$ As the anodic potential increasing to $1.07 \mathrm{~V}$, the absorption bands of the cation radical decreased gradually with a new broad band centered at around $815 \mathrm{~nm}$. The disappearance of NIR absorption band can be attributable to the further oxidation of monocation radical species to the formation of dication in the TPPA segments. The observed UV-vis-NIR absorption changes in the PAAI-2M film at various potentials are fully reversible and are associated with strong color changes. The other PAAIs showed similar spectral change to that of PAAI-2M (as shown in Supporting Information Fig. S7). From the inset shown in Figure 3(a), the PAAI-2M film switches from transparent and pale yellow neutral form to highly absorbing semioxidized green form and fully oxidized blue form. The film colorations are distributed homogeneously across the polymer film and survive for more than hundreds of redox cycles. The polymer PAAI-2M shows high contrast both in the visible and NIR regions with an extremely high-optical transmittance change $(\Delta \% T)$ of $63 \%$ at $422 \mathrm{~nm}$ and $60 \%$ at $1022 \mathrm{~nm}$ for green coloring at the first-oxidation stage, and $84 \%$ at $815 \mathrm{~nm}$ for blue coloring at the second-oxidation stage, respectively. Moreover, coloration changes were also observed in these PAAIs upon reduction. As shown in Figure 3(b), the PAAI films changed from yellow neutral form to a red reduced form, which also exhibited good contrast in the visible region with a high-optical transmittance change $(\Delta \% T)$ of $58 \%$ at $481 \mathrm{~nm}$ for red coloring at the reduction stage. Thus, these PAAIs demonstrated a good combination of redox active TPPA and bis(trimellitimide)s units for the preparation of red, green, and blue (RGB) electrochromic materials.

\section{Electrochromic Switching Studies}

The stability, response time, and color efficiency are the key parameters for an electroactive polymer film to be amenable for usage in optical and electrochromic devices, thus the electrochromic switching studies were further measured. For electrochromic switching studies, polymer films were cast on ITO-coated glass slides in the same manner as described earlier, and chronoamperometric and absorbance measurements
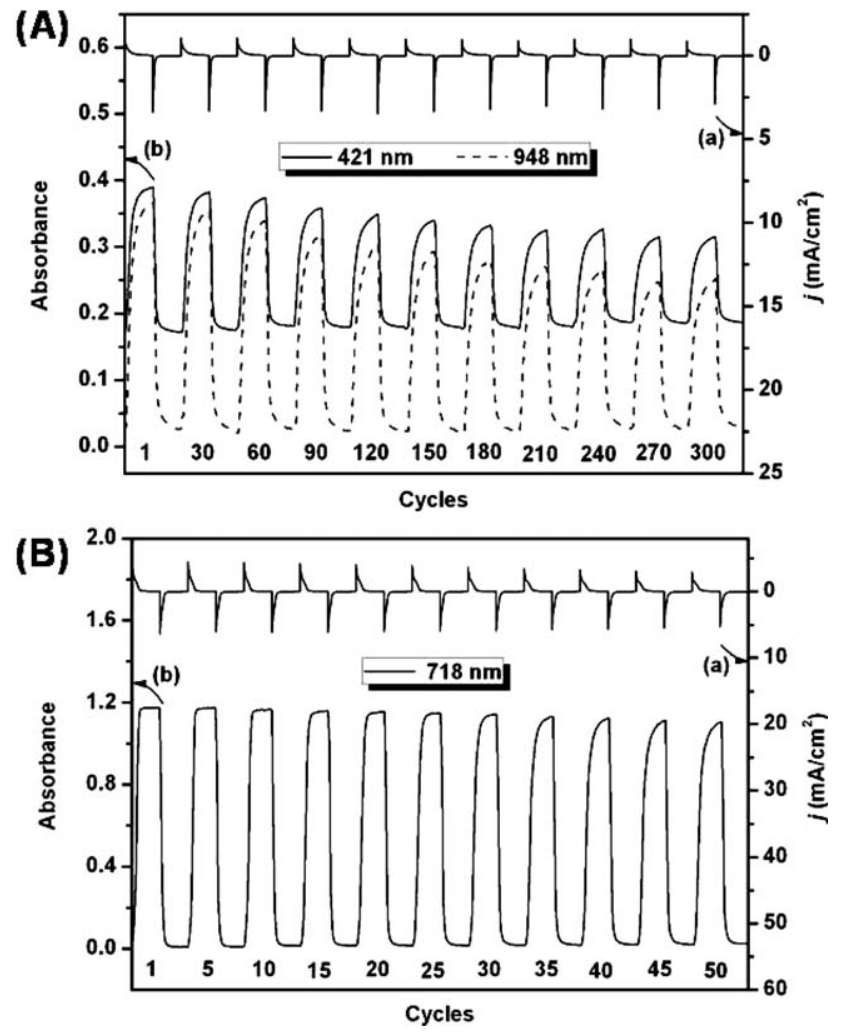

FIGURE 7 Electrochromic switching between (A) 0 and $0.85 \mathrm{~V}$ and (B) 0 and $1.35 \mathrm{~V}$ (vs. $\mathrm{Ag} / \mathrm{AgCl}$ ) of PAAI-2 $\mathbf{M}^{\prime}$ thin film ( 270 $\mathrm{nm}$ in thickness) on the ITO-coated glass substrate (coated area: $1.1 \mathrm{~cm} \times 0.5 \mathrm{~cm}$ ) in $0.1 \mathrm{M} \mathrm{TBAP} / \mathrm{CH}_{3} \mathrm{CN}$ with a cycle time of $20 \mathrm{~s}$. (a) Current consumption and (b) absorbance change monitored at the given wavelength. 
TABLE 3 Optical and Electrochemical Data Collected for Coloration Efficiency Measurements of PAAI-2M and PAAI-2M

\begin{tabular}{|c|c|c|c|c|c|c|c|c|}
\hline \multirow[b]{2}{*}{ Cycling Times $^{a}$} & \multirow[b]{2}{*}{ PAAI-2M $\delta \mathrm{OD}_{422}{ }^{\mathrm{b}}$} & \multirow[b]{2}{*}{ PAAI-2M' $\delta \mathrm{OD}_{421}{ }^{\mathrm{b}}$} & \multicolumn{2}{|c|}{$Q\left(\mathrm{mC} / \mathrm{cm}^{2}\right)^{\mathrm{c}}$} & \multicolumn{2}{|c|}{$\eta\left(\mathrm{cm}^{2} / \mathrm{C}\right)^{\mathrm{d}}$} & \multicolumn{2}{|c|}{ Decay $(\%)^{\mathrm{e}}$} \\
\hline & & & PAAI-2M & PAAI-2M' & PAAI-2M & PAAI-2M ${ }^{\prime}$ & PAAI-2M & PAAI-2M \\
\hline 1 & 0.573 & 0.390 & 3.223 & 1.565 & 178 & 249 & 0 & 0 \\
\hline 30 & 0.570 & 0.382 & 3.223 & 1.563 & 177 & 244 & 0.56 & 2.01 \\
\hline 60 & 0.570 & 0.372 & 3.223 & 1.559 & 177 & 239 & 0.56 & 4.02 \\
\hline 90 & 0.570 & 0.359 & 3.223 & 1.541 & 177 & 233 & 0.56 & 6.43 \\
\hline 120 & 0.565 & 0.348 & 3.221 & 1.537 & 175 & 226 & 1.69 & 9.24 \\
\hline 150 & 0.564 & 0.338 & 3.221 & 1.532 & 175 & 221 & 1.69 & 11.24 \\
\hline 180 & 0.560 & 0.333 & 3.220 & 1.526 & 174 & 218 & 2.25 & 12.45 \\
\hline 210 & 0.560 & 0.325 & 3.219 & 1.521 & 173 & 214 & 2.81 & 14.06 \\
\hline 240 & 0.559 & 0.324 & 3.219 & 1.511 & 173 & 214 & 2.81 & 14.06 \\
\hline 270 & 0.553 & 0.314 & 3.217 & 1.505 & 172 & 209 & 3.37 & 16.06 \\
\hline 300 & 0.547 & 0.313 & 3.216 & 1.504 & 170 & 208 & 4.49 & 16.47 \\
\hline
\end{tabular}

a Switching between 0 and 0.74 for PAAl-2M, 0 and 0.85 for PAAl-2M', respectively (V vs. Ag/AgCl).

${ }^{\mathrm{b}}$ Optical density change at the given wavelength.

${ }^{\mathrm{c}}$ Ejected charge, determined from the in situ experiments.

${ }^{\mathrm{d}}$ Coloration efficiency is derived from the equation $\eta=\delta \mathrm{OD} / Q$.

${ }^{e}$ Decay of coloration efficiency after cyclic scans.

were performed. Although the films were switched, the absorbance at the given wavelength was monitored as a function of time with UV-vis-NIR spectroscopy. Switching data for the representative cast film of polymer PAAI-2M (with 4,4'-dimethoxy-substituted) and PAAI-2M $\mathbf{M}^{\prime}$ (without 4,4'dimethoxy-substituted) were shown in Figures 5-7 for comparison. The switching time was calculated at $90 \%$ of the full switch because it is difficult to perceive any further color change with naked eye beyond this point. As depicted in Figure 5(A), PAAI-2M film revealed switching time of $2.91 \mathrm{~s}$ at $0.76 \mathrm{~V}$ for coloring process at $422 \mathrm{~nm}$ and $1.32 \mathrm{~s}$ for bleach- ing. When the potential was set at $1.07 \mathrm{~V}$, PAAI-2M film required $3.23 \mathrm{~s}$ for coloration at $815 \mathrm{~nm}$ and $2.05 \mathrm{~s}$ for bleaching [Fig. 5(B)]. The PAAIs switched rapidly between the highly transmissive neutral state and the colored oxidized state. As shown in Figures 6 and 7, the electrochromic stability of the polymer PAAI-2M and PAAI-2M' films were determined by measuring the optical change as a function of the number of switching cycles. The electrochromic CE $(\eta=$ $\delta \mathrm{OD} / Q$ ) and injected charge (electroactivity) after various switching steps were monitored and summarized in Tables 3 and 4. The electrochromic film of PAAI-2M was found to

TABLE 4 Optical and Electrochemical Data Collected for Coloration Efficiency Measurements of PAAI-2M and PAAI-2M'

\begin{tabular}{|c|c|c|c|c|c|c|c|c|}
\hline \multirow[b]{2}{*}{ Cycling Times $^{a}$} & \multirow[b]{2}{*}{ PAAI-2M $\delta \mathrm{OD}_{815}{ }^{\mathrm{b}}$} & \multirow[b]{2}{*}{ PAAI-2M' $\delta \mathrm{OD}_{718^{b}}$} & \multicolumn{2}{|c|}{$Q\left(\mathrm{mC} / \mathrm{cm}^{2}\right)^{\mathrm{c}}$} & \multicolumn{2}{|c|}{$\eta\left(\mathrm{cm}^{2} / \mathrm{C}\right)^{\mathrm{d}}$} & \multicolumn{2}{|c|}{ Decay $(\%)^{e}$} \\
\hline & & & PAAI-2M & PAAI-2M' & PAAI-2M & PAAI-2M' & PAAI-2M & PAAI-2M' \\
\hline 1 & 1.311 & 1.173 & 5.410 & 5.316 & 242 & 221 & 0 & 0 \\
\hline 5 & 1.311 & 1.173 & 5.410 & 5.315 & 242 & 221 & 0 & 0 \\
\hline 10 & 1.311 & 1.165 & 5.410 & 5.315 & 242 & 219 & 0 & 0.95 \\
\hline 15 & 1.311 & 1.157 & 5.410 & 5.313 & 242 & 218 & 0 & 1.36 \\
\hline 20 & 1.311 & 1.149 & 5.410 & 5.313 & 242 & 216 & 0 & 2.26 \\
\hline 25 & 1.311 & 1.146 & 5.410 & 5.313 & 242 & 216 & 0 & 2.26 \\
\hline 30 & 1.310 & 1.141 & 5.409 & 5.313 & 242 & 215 & 0 & 2.71 \\
\hline 35 & 1.304 & 1.125 & 5.409 & 5.311 & 241 & 212 & 0.41 & 4.07 \\
\hline 40 & 1.297 & 1.124 & 5.408 & 5.311 & 240 & 212 & 0.83 & 4.07 \\
\hline 45 & 1.285 & 1.108 & 5.407 & 5.311 & 238 & 209 & 1.65 & 5.43 \\
\hline 50 & 1.279 & 1.100 & 5.407 & 5.311 & 237 & 207 & 2.07 & 6.33 \\
\hline
\end{tabular}

${ }^{a}$ Switching between 0 and 1.16 for PAAI-2M, 0 and 1.35 for PAAI-2M', respectively (V vs. Ag/AgCl).

b Optical density change at the given wavelength.

${ }^{\mathrm{c}}$ Ejected charge, determined from the in situ experiments.

${ }^{\mathrm{d}}$ Coloration efficiency is derived from the equation $\eta=\delta \mathrm{OD} / Q$.

e Decay of coloration efficiency after cyclic scans. 
show good CE up to $178 \mathrm{~cm}^{2} / \mathrm{C}$ at $422 \mathrm{~nm}\left(185 \mathrm{~cm}^{2} / \mathrm{C}\right.$ at $1022 \mathrm{~nm}$ ), and to retain more than $99 \%$ of their electroactivity after switching 300 times between 0 and $0.74 \mathrm{~V}$ [Fig. 6(A)]. As the applied switching potential increased to $1.16 \mathrm{~V}$, a higher CE $\left(242 \mathrm{~cm}^{2} / \mathrm{C}\right.$ at $\left.815 \mathrm{~nm}\right)$ could be obtained and showed only $0.1 \%$ decay of its electroactivity after 50 cycles [Fig. 6(B)]. On the contrary, the corresponding PAAI-2M' without the para-methoxy substituted on TPPA units gradually lost $\delta O D$ change after several cyclic switches (Fig. 7). The result also consists with the improvement of PAAI-2M in electrochemical studies by the introduction of para-substituted methoxy group on the TPPA unit.

\section{CONCLUSIONS}

A series of novel NIR electroactive TPPA-based PAAIs were readily prepared from the $(\mathrm{OMe})_{2}$ TPPA-based diamine monomer with various aromatic diimide-diacids via the phosphorylation polyamidation reaction. Introduction of electrondonating para-methoxy substituted on TPPA unites not only stabilizes its cationic radicals and dications but also leads to good solubility and uniform amorphous films using solutioncasting techniques. In addition to high $T_{\mathrm{g}}$, good thermal stability, notable low-switching times, high CE, and excellent electroactive reversibility, the polymers also revealed interesting electrochromic characteristics with color change from pale yellow neutral state to green/blue oxidized states and red reduced state. The result provides the strategies for the design of functional polymers with RGB electrochromism. Thus, these characteristics suggest that these novel $(\mathrm{OMe})_{2}$ TPPA-based PAAIs have great potential for multicolored electrochromic applications in both visible and NIR region.

We are grateful to the National Science Council of the Republic of China for financial support of this work.

\section{REFERENCES AND NOTES}

1 Monk, P. M. S.; Mortimer, R. J.; Rosseinsky, D. R. Electrochromism and Electrochromic Devices; Cambridge University Press: Cambridge, UK, 2007.

2 (a) Bach, U.; Corr, D.; Lupo, D.; Pichot, F.; Ryan, M. Adv Mater 2002, 14, 845-848; (b) Dyer, A. L.; Grenier, C. R. G.; Reynolds, J. R. Adv Funct Mater 2007, 17, 1480-1486; (c) Ma, C.; Taya, M.; Xu, C. Polym Eng Sci 2008, 48, 2224-2228; (d) Beaupre, S.; Breton, A. C.; Dumas, J.; Leclerc, M. Chem Mater 2009, 21, 1504-1513.

3 (a) Bange, K.; Gambke, T. Adv Mater 1990, 2, 10-16; (b) Mortimer, R. J. Chem Soc Rev 1997, 26, 147-156; (c) Rosseinsky, D. R.; Mortimer, R. J. Adv Mater 2001, 13, 783-793; (d) Somani, P. R.; Radhakrishnan, S. Mater Chem Phys 2003, 77, 117-133; (e) Lee, S. H.; Deshpande, R.; Parilla, P. A.; Jones, K. M.; To, B.; Mahan, H.; Dillon, A. C. Adv Mater 2006, 18, 763-766; (f) Zhang, T.; Liu, S.; Kurth, D. G.; Faul, C. F. J. Adv Funct Mater 2009, 19, 642-652; (g) Maier, A.; Rabindranath, A. R.; Tieke, B. Adv Mater 2009, 21, 959-963; (h) Li, M.; Sheynin, Y.; Patra, A.; Bendikov, M. Chem Mater 2009, 21, 2482-2488.
4 (a) Rose, T. L.; D'Antonio, S.; Jillson, M. H.; Kon, A. B.; Suresh, R.; Wang, F. Synth Met 1997, 85, 1439-1440; (b) Franke, E. B.; Trimble, C. L.; Hale, J. S.; Schubert, M.; Woollam, J. A. J Appl Phys 2000, 88, 5777-5784; (c) Topart, P.; Hourquebie, P. Thin Solid Films 1999, 352, 243-248.

5 (a) Vickers, S. J.; Ward, M. D. Electrochem Commun 2005, 7, 389-393; (b) Schwab, P. F. H.; Diegoli, S.; Biancardo, M.; Bignozzi, C. A. Inorg Chem 2003, 42, 6613-6615; (c) Wang, S.; Todd, E. K.; Birau, M.; Zhang, J.; Wan, X.; Wang, Z. Y. Chem Mater 2005, 17, 6388-6394; (d) Qiao, W.; Zheng, J.; Wang, Y.; Zheng, Y.; Song, N.; Wan, X.; Wang, Z. Y. Org Lett 2008, 10, 641-644; (e) Qi, Y.; Wang, Z. Y. Macromolecules 2003, 36, 3146-3151.

6 (a) Creutz, C.; Taube, H. J Am Chem Soc 1973, 95, 1086-1094; (b) Lambert, C.; Noll, G. J Am Chem Soc 1999, 121, 8434-8442.

7 Robin, M.; Day, P. Adv Inorg Radiochem 1967, 10, 247-422.

8 Szeghalmi, A. V.; Erdmann, M.; Engel, V.; Schmitt, M.; Amthor, S.; Kriegisch, V.; Noll, G.; Stahl, R.; Lambert, C.; Leusser, D.; Stalke, D.; Zabel, M.; Popp, J. J Am Chem Soc 2004, 126, 7834-7845.

9 (a) Thelakkat, M. Macromol Mater Eng 2002, 287, 442-461; (b) Shirota, Y. J Mater Chem 2005, 15, 75-93; (c) Shirota, Y.; Kageyama, H. Chem Rev 2007, 107, 953-1010; (d) Kuorosawa, T.; Chueh, C. C.; Liu, C. L.; Higashihara, T.; Ueda, M.; Chen, W. C. Macromolecules 2010, 43, 1236-1244.

10 (a) Oishi, Y.; Ishida, M.; Kakimoto, M. A.; Imai, Y.; Kurosaki, T. J Polym Sci Part A: Polym Chem 1992, 30, 1027-1035; (b) Liou, G. S.; Hsiao, S. H.; Ishida, M.; Kakimoto, M. A.; Imai, Y. J Polym Sci Part A: Polym Chem 2002, 40, 3815-3822; (c) Leung, M. K.; Chou, M. Y.; Su, Y. O.; Chiang, C. L.; Chen, H. L.; Yang, C. F.; Yang, C. C.; Lin, C. C.; Chen, H. T. Org Lett 2003, 5, 839-842; (d) Chou, M. Y.; Leung, M. K.; Su, Y. O.; Chiang, C. L.; Lin, C. C.; Liu, J. H.; Kuo, C. K.; Mou, C. Y. Chem Mater 2004, 16, 654-661; (e) Otero, L.; Sereno, L.; Fungo, F.; Liao, Y. L.; Lin, C. Y.; Wong, K. T. Chem Mater 2006, 18, 3495-3502.

11 (a) Cheng, S. H.; Hsiao, S. H.; Su, T. X.; Liou, G. S. Macromolecules 2005, 38, 307-316; (b) Su, T. X.; Hsiao, S. H.; Liou, G. S. J Polym Sci Part A: Polym Chem 2005, 43, 2085-2098.

12 (a) Liou, G. S.; Hsiao, S. H.; Su, T. X. J Mater Chem 2005, 15, 1812-1820; (b) Liou, G. S.; Yang, Y. L.; Su, Y. O. J Polym Sci Part A: Polym Chem 2006, 44, 2587-2603; (c) Liou, G. S.; Hsiao, S. H.; Chen, H. W. J Mater Chem 2006, 16, 1831-1842; (d) Liou, G. S.; Hsiao, S. H.; Huang, N. K.; Yang, Y. L. Macromolecules 2006, 39, 5337-5346; (e) Liou, G. S.; Chen, H. W.; Yen, H. J. J Polym Sci Part A: Polym Chem 2006, 44, 4108-4121; (f) Liou, G. S.; Chen, H. W.; Yen, H. J. Macromol Chem Phys 2006, 207, 1589-1598; (g) Liou, G. S.; Chang, C. W.; Huang, H. M.; Hsiao, S. H. J Polym Sci Part A: Polym Chem 2007, 45, 2004-2014; (h) Liou, G. S.; Yen, H. J.; Chiang, M. C. J Polym Sci Part A: Polym Chem 2009, 47, 5378-5385.

13 (a) Mazur, S.; Lugg, P. S.; Yarnilzky, C. J Electrochem Soc 1987, 134, 346-353; (b) Viehbeck, A.; Goldberg, M. J.; Kovac, C. A. J Electrochem Soc 1990, 137, 1460-1466; (c) Krause, L. J.; Lugg, P. S.; Speckhard, T. A. J Electrochem Soc 1989, 136, 1379-1385.

14 (a) Chang, C. W.; Liou, G. S.; Hsiao, S. H. J Mater Chem 2007, 17, 1007-1015; (b) Liou, G. S.; Chang, C. W. Macromolecules 2008, 41, 1667-1674; (c) Hsiao, S. H.; Liou, G. S.; Kung, Y. C.; Yen, H. J. 
Macromolecules 2008, 41, 2800-2808; (d) Chang, C. W.; Chung, C. H.; Liou, G. S. Macromolecules 2008, 41, 8441-8451; (e) Chang, C. W.; Yen, H. J.; Huang, K. Y.; Yeh, J. M.; Liou, G. S. J Polym Sci Part A: Polym Chem 2008, 46, 7937-7949; (f) Yen, H. J.; Liou, G. S. Chem Mater 2009, 21, 4062-4070.

15 Yang, C. P.; Liou, G. S.; Yang, C. C.; Tseng, N. W. Polym Bull 1999, 42, 1-8.

16 Yang, C. P.; Liou, G. S.; Yang, C. C.; Chen, S. H. Polym Bull 1999, 43, 21-28.

17 Yang, C. P.; Liou, G. S.; Chang, S. Y.; Chen, S. H. J Appl Polym Sci 1999, 73, 271-278.
18 Yamazaki, N.; Matsumoto, M.; Higashi, F. J Polym Sci Polym Chem Ed 1975, 13, 1373-1380.

19 Cheng, S. H.; Hsiao, S. H.; Su, T. H.; Liou, G. S. Polymer 2005, 46, 5939-5948.

20 Wang, P.; Chai, C.; Yang, Q.; Wang, F.; Shen, Z.; Guo, H.; Chen, X.; Fan, X.; Zou, D.; Zhou, Q. J Polym Sci Part A: Polym Chem 2008, 46, 5452-5460; (b) Karastatiris, P.; Mikroyannidis, J. A.; Spiliopoulos, I. K. J Polym Sci Part A: Polym Chem 2008, 46, 2367-2378.

21 Liaw, D. J.; Chang, F. C.; Leung, M. K.; Chou, M. Y.; Muellen, K. Macromolecules 2005, 38, 4024-4029. 